\title{
THE FOREIGN GOD AND THE SUDDEN CHRIST: THEOLOGY AND CHRISTOLOGY IN MARCION'S GOSPEL REDACTION
}

\author{
Peter Head
}

\section{Summary}

This article seeks to establish the extent to which Marcion's Christology influenced the formation of his gospel canon, the Euaggelion. Marcion's Christology, as seen in statements preserved in Irenaeus, Tertullian and Epiphanius, has features that can be described as both docetic and modalist. These christological beliefs effect Marcion's redaction of the Pauline epistles and his omission of material from Luke's Gospel. In particular the omission of the birth narratives and notices relating to the humanity of Jesus suggest the appropriateness of Tertullian's slogan: 'the sudden Christ'.

\section{Introduction}

Marcion is, at least in general terms if not in detail, a well known figure in second century Christianity. In some circles he is also a popular figure; although not everyone would be happy describing him as a 'Christian scholar, church leader, and reformer' ${ }^{1} \mathrm{He}$ is certainly an important figure who, perhaps more than any other, influenced the text and canon of the NT decisively in the early period. ${ }^{2}$ His work is also of interest in

${ }^{1} \mathrm{H}$. Koester, Ancient Christian Gospels: Their History and Development (London, SCM; Philadelphia, TPI 1990) 35.

${ }^{2}$ For a general introduction see B.M. Metzger, The Canon of the New Testament: Its Origin, Development, and Significance (Oxford, Clarendon 1987) 90-99. Of other literature A. von Harnack, Marcion: Das Evangelium vom fremden Gott. Eine Monographie zur Geschichte der Grundlegung der katholischen Kirche (2nd ed.: TU 45; Leipzig, Hinrichs 1924) remains unsurpassed as a resource (partial ET: Marcion: the gospel of the alien God [Durham NC, Labyrinth 1990]). For Harnack's earlier views see his 'Marcion and the Marcionite Churches' Encyclopedia Britannica. Ninth Edition (Edinburgh, A. \& C. Black 1888) Vol 15, 533-535. Also valuable are O. Bardenhewer, Geschichte der altkirchlichen Literatur. Erster Band: Vom Ausgang des apostolischen Zeitalters bis zum Ende des zweiten Jahrhunderts (Darmstadt, Wissenschaftliche Buchgesellschaft 1962) 371-376; E.C. Blackman, Marcion and his Influence (London, SPCK 1948); J. Quasten, Patrology (3 vols.; Utrecht, Spectrum 1950-1953) 1, 268-272. For a recent 
terms of the influence of theological and christological factors upon his transmission and redaction of gospel traditions and it is this topic which will be explored in what follows. We shall begin with a brief introduction to Marcion and his theology (II); this will be followed by a discussion of Marcion's Christology (III); which leads into the main part of the article which consists of an assessment of Marcion's redactional activity in connection with both the Pauline corpus and the gospel of Luke (IV). A brief conclusion $(\mathrm{V})$ summarises the results of the study. ${ }^{3}$

\section{Marcion and His Theology}

Marcion was a native of Pontus, born late in the first century, who became a wealthy shipowner. He was brought up in the church (according to Hippolytus he was the son of a bishop), 4 and upon arrival in Rome (around A.D. 140) he joined the church there. Tertullian claimed knowledge of a letter written by Marcion to the church at Rome which indicated that Marcion was then 'orthodox' (Adv. Marc. I.1; IV.4; de Carne 2). Here he apparently came under the influence of Cerdo, 5 a gnostic teacher who 'taught that the God proclaimed by the Law and the Prophets was not the father of our Lord Jesus Christ. For the former was known, but the latter unknown; while the one also was righteous, but the other benevolent ${ }^{\prime}$ (Irenaeus, Adv. Haer. I.27.2, quoted also in Eusebius, Hist. Eccl. IV.11.2). Marcion was soon openly declaring his beliefs and

survey see G. May, 'Marcion in Contemporary Views: Results and Open Questions' SecCent 6 (1987-1988) 129-152.

${ }^{3} \mathrm{Cf}$. our previous investigation of 'Tatian's Christology and its Influence on the Composition of the Diatessaron', Tyn Bull 43 (1992) 121-137.

4See Harnack, Marcion, 23.

${ }^{5}$ According to Irenaeus, Marcion succeeded Cerdo and developed his doctrine (Adv. Haer. I.27.1; III.4.3); similar statements are made by later Fathers: Tertullian, Adv. Marc. I.2, 22; III.21; IV.17; Hippolytus, Refut. 10.15; Eusebius, Hist. Eccl. IV.10. The nature of the relationship is discussed, and minimised, by Harnack (Marcion, 31*-39*). While it obviously suited the polemical interests of the Fathers to link these two, there is little reason to deny any connection (as does R.J. Hoffmann, Marcion: On the Restitution of Christianity. An Essay on the Development of Radical Paulinist Theology in the Second Century [AARAS 46; California, Scholars Press 1984] 33f., 40f-44). Cf. also P.N. Harrison, Polycarp's Two Epistles to the Philippians (Cambridge, Cambridge University Press 1936) 184-191. 
inviting comments from the elders of the Roman church. His views were not found agreeable and he was officially excommunicated from the Roman church in A.D. 144. 6 At this point Marcion set up his own church, rivalling the orthodox church in structure and organisation, until he died about A.D. 160.7 Marcion was a gifted administrator and by the middle of

6Harnack, Marcion, 26; Blackman, Marcion, 2f.; Epiphanius, Panarion, 42.2.

7It must be acknowledged that we have little firm evidence for some of these dates. The basis is Tertullian's report that the Marcionites posit 115 years and $6 \& 1 / 2$ months between Christ and Marcion (Adv. Marc. I.19). Harnack (Marcion, 29; followed by Blackman, Marcion, 3 n. 1) takes this to refer to Marcion's exclusion from the Roman church (which results in A.D. 144, counting from the death of Christ). Several scholars have argued that Marcion was actively teaching his heretical views long before his arrival in Rome. Polycarp attacks an unnamed docetist who twists the logia of the Lord and who is called 'the first-born of Satan' (Philippians 7). Since Irenaeus reports that Polycarp later used a similar expression of Marcion (Adv. Haer. III.3.4), some have suggested that Polycarp must have been opposing Marcion in the earlier epistle, whether in A.D. 110 (so Hoffmann, Marcion, 51f.) or if the epistle is split up, between 130 and 135 (so Harrison, Polycarp's, 172-206; J. Knox, Marcion and the New Testament. An Essay in the Early History of the Canon (Chicago, University of Chicago Press 1942) 9-12). In addition, the statements of Irenaeus and Justin concerning the spread and continuing influence of Marcion's teaching (Irenaeus, Adv. Haer. III.4.3; Justin, Apol. 26) are taken to imply a longer period of ministry and influence than is otherwise allowed for (see Hoffmann, Marcion, 44-56).

Against this it must be asserted that Polycarp's description does not really fit Marcion (see J.B. Lightfoot, The Apostolic Fathers, Part II. S. Ignatius, S. Polycarp [3 vols.; 2nd ed.; Macmillan \& Co., 1889] vol. 1, 585-588). Polycarp's adversary did not confess the testimony of the cross, and denied the resurrection and the judgement (unlike Marcion); nor does the term $\mu \varepsilon \theta 0 \delta \varepsilon v$ in adequately describe Marcion's textual excisions (it more suggests tortuous interpretation). Hoffmann (Marcion, 53-56) marshalls arguments for a Marcionite background to the epistle of Polycarp, but these are unconvincing, merely showing that traditional post-apostolic Christianity was incompatible with Marcionism (if Marcion was a perceived threat then the two main issues of ditheism and the place of the OT must have been forthrightly addressed). Polycarp's 'first-born of Satan' probably refers to a 'traditional' docetist of the type criticised in the Johannine epistles (cf., the use of 1 Jn. 4:2f. in Polycarp, Philippians 7). Hoffmann's further attempts to find references to Marcion's heresy in the epistles of Ignatius (Marcion, 57-63) are also unconvincing (on Hoffmann in general see C.P. Bammel's review in JTS 39 [1988] 227-232). Hoffmann has discussed his thesis further in 'How then Know This Troublous 
the second century it could be said that members of his church could be found throughout the Empire (according to Justin, Apol. 1.26; cf., I.58; Tertullian, Adv. Marc. IV.19). Following his death the Marcionite 'church' continued to expand, not dying out until the fourth and fifth centuries.8

The extent of Marcion's influence may be judged by the status and number of his critics: 9 Dionysius of Corinth; Irenaeus of Lyons; Theophilus of Antioch; Philip of Gortyna; Tertullian at Carthage; Hippolytus and Rhodo at Rome; Bardesanes at Edessa; as well as by the quantity and quality of their individual responses (e.g. Tertullian's five books Adversus Marcionem). 10

Marcion's theology was dominated by the antithesis between the OT Creator God of Law (the Demiurge) and Jesus' God of love and grace. According to Tertullian, 'the principal, and consequently the entire, matter of discussion is one in number, whether it is permissible to suggest the existence of two gods' (Adv. Marc. I.3.1). For Marcion only Paul, among the disciples of Jesus, had fully understood the doctrines of grace. 11

Teacher? Further Reflections on Marcion and his Church', SecCent 6 (19871988) 173-191.

${ }^{8}$ Harnack, Marcion, 153-160; H.J.W. Drijvers, 'Marcionism in Syria: Principles, Problems, Polemics', SecCent 6 (1987-1988) 153-172.

${ }^{9}$ See, in addition to those mentioned here, Eusebius, Hist. Eccl. IV.23.4 (Dionysius); IV.24 (Theophilus); IV.25.1 (Philip, Irenaeus, Modestus, 'and there are many others too'); Hoffmann, Marcion, 33; and ODCC, 870.

${ }^{10}$ Tertullian, Adv. Marc. and Epiphanius, Panarion 42 provide information concerning the text of Marcion's Bible. Epiphanius lists 78 passages from Marcion's Euaggelion (Panarion 42.11.6), and then discusses each one (Panarion 42.11.17). We shall refer to these passages as Scholia 1-78 (with Harnack, and D.S. Williams, 'Reconsidering Marcion's Gospel' JBL 108 [1989] 477-496). The editions used are: E. Evans, Tertullian: Adversus Marcionem (2 vols.; Oxford, Clarendon 1972); Epiphanius, Ancoratus, Panarion \& De Fide (3 vols.; K. Holl (ed.); Leipzig, J.C. Hinrich; GCS 25: Ancoratus \& Panarion 1-33, 1915; GCS 31: Panarion 34-64, 1922; GCS 37: Panarion 65-80 \& De Fide, 1933). English translations of other patristic writers are taken from A. Roberts and J. Donaldson (eds.), Ante-Nicene Christian Library. Translations of the Writings of the Fathers down to A.D. 325 (24 vols.; Edinburgh, T. \& T. Clark 1867-1872, and modern reprints).

${ }^{11} \mathrm{Cf}$. Harnack's famous statement that in the 2nd century only one Christian-Marcion-took the trouble to understand Paul; but...he misunderstood him.' ('Marcion and the Marcionite Churches', 534, cf. also History of Dogma [ET of 1893; 3rd German edition; 7 vols.; London, Williams \& Norgate 1894-1899] vol. 1, 89). 
Marcion produced an edited version of ten Pauline epistles 12 and the Gospel of Luke: the Apostolikon and the Euaggelion respectively. ${ }^{13}$ In addition he wrote another work entitled Antitheses in which he set forth his doctrines systematically.

Marcion believed that the true gospel of grace had been corrupted by Jewish influences, and in particular that the more Jewish followers of Jesus had adulterated the message. Therefore he saw his task as restoration (cf. Tertullian, Adv. Marc. IV.3-5). Although some have suggested that canonical Luke is a response to Marcion's Gospel, the consensus supports the view of Tertullian and the other Fathers that Marcion's work is a form of gospel redaction.14 As Irenaeus saw it, Marcion was 'the only one who has dared openly to mutilate the Scriptures' (Adv. Haer. I.27.4). He further said:

He mutilates the Gospel which is according to Luke, removing all that is written respecting the generation of the Lord, and setting aside a great deal of the teaching of the Lord, in which the Lord is

${ }^{12}$ Although he probably labelled them as seven epistles (Knox, Marcion, 39-46).

${ }^{13}$ These works are not extant, but various attempts to reconstruct the text from the quotations and discussions in the Fathers have been made. We follow Harnack's reconstruction here (the Euaggelion is in Marcion; 183*$240^{*}$, the Apostolikon on pp. $\left.67^{*}-127^{*}\right)$. This took over from Zahn's reconstruction ('Marcions Neues Testament', Geschichte des Neutestamentlichen Kanons II:2 [Erlangen \& Leipzig, A. Deichert 1892] 409$529)$ as the standard text, and has yet to be surpassed. Harnack supplies lists of omissions (Marcion, 52-59) and corrections (pp. 59-61) made by Marcion to the Lukan text. It is customary to refer to Marcion's text by the Lukan position, i.e. 8:28 means the place in Marcion's Euaggelion which corresponds to Luke 8:28. On the Apostolikon see Marcion, 45-51.

${ }^{14}$ The view that Luke is a secondary redaction of Marcion's Euaggelion has a long history. It was prominent in the Tübingen School, and conclusively opposed by Volkmar and Hilgenfeld, see H. Harris, The Tübingen School (Oxford, Clarendon 1975) 226f. The most recent resuscitation is Hoffmann's Marcion. Against this hypothesis it must be insisted that there does not seem to be any evidence of the necessary collusion amongst the early Fathers and Tertullian's reports that a) Marcion himself claimed that the Jewish apostles had falsified the gospel of Luke; and b) Marcion's task was to restore the original (Marc IV.4; cf., also IV.5.6); should stand (cf. also A. Loisy 'Marcion's Gospel: A Reply', HibJ 34 (1936) 378-387 responding to P.-L. Couchoud, 'Is Marcion's Gospel one of the Synoptics?', HibJ 34 [1936] 265-277). 
recorded as most clearly confessing that the Maker of this universe is His Father. ${ }^{15}$

Tertullian is particularly strident on this point: 'What Pontic mouse is more corrosive than the man who has gnawed away the Gospels?' (Adv. Marc. I.1.5). Tertullian also suggests that Marcion had distinctive interpretations for some of the material he left in (Adv. Marc. IV.43). He set out to refute Marcion's theology from his own text, arguing that Marcion's emendations and mutilations served to prove the temporal priority of the orthodox text (Adv. Marc. IV.3-6, esp. 4).

Marcion's main policy was redaction by omission. The vast majority of his alterations to the text of the New Testament were of this nature, whether whole books, chapters, particular pericopae, verses or even single words. ${ }^{16} \mathrm{He}$ criticised with a knife. Two factors appear to have motivated Marcion's editorial activities. The main factor is his contrast between the two gods, and thus between law and grace. This explains, for example, his attitude to the OT, and to OT quotations within the NT (which were entirely omitted); as well as his omission of Romans 3:314:25 and the bulk of Romans 9-11. This is continually present in his alteration of the gospel texts as well, as we shall see. The second factor, which we shall highlight in the following sections of this paper, was christological. B. Aland suggests that the importance of Marcion's Christology has been underemphasised in recent scholarly treatments. She argues that Marcion's 'absolutely indefensible christology' was as important as his distinction between two gods in provoking his expulsion from the church. ${ }^{17}$

\section{Marcion's Christology}

Marcion's Christology was developed in an age of great theological diversity, before the constructions expressed in the classical creeds had been formulated. In this period there was

${ }^{15}$ Irenaeus, Adv. Haer. 1.27.2. Irenaeus also refers to Marcion's dismembering of the Pauline epistles by removing OT quotations and references to the God who made the world being the Father of Jesus.

16Even the selection of only one gospel was regarded as an act of violence to the canonical record (cf., Tertullian, Adv. Marc IV.3).

17'Marcion-Marcionites-Marcionism', Encyclopedia of the Early Church (ed.

A.D. Berardino; Cambridge, James Clarke \& Co. 1992; 2 vols.) 1, $523 \mathrm{f}$. 
an understandable diversity even within 'orthodox' groups. 18 Clearly outside 'orthodoxy', however, were the gnostics and the docetists. Marcion's Christology appears to have been a combination of elements from these two thought-worlds.

Marcion never makes clear, at least not in a way that we can reconstruct, just how he envisaged the nature of Jesus' body. ${ }^{19} \mathrm{He}$ does, however, make use of an analogy in which the body of Jesus is compared with the angels of the Creator who met with Abraham and Lot. These angels, while existing 'in a phantasm, evidently of putative flesh' ${ }^{20}$ nevertheless were able to converse, and eat and work in that state. That Marcion did affirm a similar Christology is undeniable, since he regularly uses $\phi \alpha \dot{\tau} \tau \alpha \sigma \mu \alpha$ to describe Christ's body. ${ }^{21} \mathrm{He}$ denied the salvation of the body; only the souls of men would be saved,22 since for him the physical body comes from the Creator God, with whom Jesus had nothing to do. According to Tertullian, Marcion held the flesh of Christ to be imaginary, and his nativity to be a phantom;23 elsewhere Tertullian describes Christ's body as 'putative corporeity'.24 Marcion held that Christ was never born, because it was unworthy. ${ }^{25}$ The

18Perhaps over-estimated in the classic study by W. Bauer, Rechtgläubigkeit und Ketzerei im ältesten Christentum (BhTh 10; Tübingen, Mohr 1934, 1964 2nd. ed.); ET: Orthodoxy and Heresy in Earliest Christianity (London, SCM 1972). See the early response by H.E.W. Turner, The Pattern of Christian Truth: A Study in the Relations Between Orthodoxy and Heresy in the Early Church (London, Mowbray 1954). And more recently T.A. Robinson, The Bauer Thesis Examined: The Geography of Heresy in the Early Christian Church (Lewiston/Queenston, Edwin Mellen 1988).

${ }^{19}$ Later Marcionites became more explicit, for example Apelles, a disciple of Marcion, argued that Christ had a body of real flesh made up of some kind of cosmic material: 'He borrowed his flesh from the stars, and from the substances of the higher world' (de sideribus et de substantiis superioris mundi mutuatus est carnem; Tertullian, de Carne 6).

${ }^{20}$ 'in phantasmate, putativae utique carnis' (Tertullian, Adv. Marc. III.9.1; cf., de Carne 3).

${ }^{21}$ Tertullian, de Carne 1,2; Adv. Marc. III.10,11; IV.7.1-5; III.8.1; V.8.3; V.20.3, cf., Luke $24.39 \mathrm{f}$ and Harnack, Marcion, $125 \mathrm{f}$.

22Irenaeus, Adv. Haer. I.27.3.

${ }^{23}$ Tertullian, de Carne 1; cf., Adv. Marc. III.11, and also III.8.1: 'he maintains that Christ was a phantasm'.

24Tertullian, Adv. Marc. III.11.1; cf., also IV.10.15f. and III.8.2 on Marcion's denial of the reality of Christ's body. Theodoret described Marcion as a docetist (Epistle 82).

25Tertullian, de Carne 2-4; Adv. Marc. III.8. 
incarnation is incredible, since for Marcion the god whom Christ reveals is not the creator of flesh. 26

Blackman summarises Marcion's Christology:

he is the son of the good God, in a modalistic sense. He cannot have had a body of flesh and blood, for these are earthly elements. As he is himself independent of the World-Creator and all his works, so he demands that men also shall free themselves from the Creator and from this world. 27

Notwithstanding the fact that Irenaeus and the other apologists tended to label Marcion as a gnostic, it is probably a misleading label. Certainly he was very influenced by gnosticism, through the ideas of Cerdo; and the fundamental theory of two gods: one the creator deity and the other god of love, may come from a gnostic environment. Nevertheless, the lack of speculative ideas, the allegiance to Paul, and the aversion to allegorical exegesis distance Marcion from the gnostics. ${ }^{28}$

\section{Theological Factors in Marcion's Redaction}

\section{The Apostolikon}

Marcion's Apostolikon begins with Galatians. ${ }^{29}$ The opening

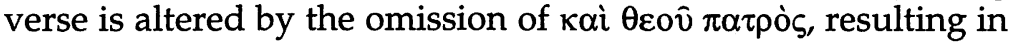
the phrase 'through Jesus Christ who raised himself from the dead'. ${ }^{30}$ This alteration is often taken as indicating Marcion's modalism. ${ }^{31}$ Although Marcion does occasionally omit or alter

${ }^{26}$ Cf., Tertullian, Adv. Marc. III.10.1: Marcion's Creator god despises the flesh as 'packed with dung'.

27Blackman, Marcion, 48.

${ }^{28}$ See further B. Aland, 'Marcion. Versuch einer neuen Interpretation', ZTK 70 (1973) 420-447 (against Harnack's dismissal of gnostic elements in Marcion's thought); U. Bianchi, 'Marcion: Théologien biblique ou docteur gnostique?', VC 21 (1967) 141-149; J.C. Gager, 'Marcion and Philosophy', VC 26 (1972) 53-59.

${ }^{29}$ The principles behind Marcion's arrangement of the Apostolikon are discussed in Knox, Marcion, 39-76; on Galatians in particular see also Blackman, Marcion, 42f. The placing of Galatians first is understandable in the light of its strongly antithetical statements (although even this epistle was severely edited, Harnack, Marcion, 45-48).

${ }^{30}$ Harnack, Marcion, 45 cf., $67^{*} \mathrm{f}$ (based on Tertullian, Adv. Marc. V.1.3; Jerome, Gal. 1.1).

31Harnack, Marcion, 45; Blackman, Marcion, 44 n. 2. Baarda disputes the modalistic interpretation, since Marcion's text is uncertain, and at Rom. 
the Pauline expression 'the God and Father of our Lord Jesus Christ'; ${ }^{32}$ he does not do this regularly, ${ }^{33}$ and indeed we have scarcely any evidence for the bulk of the Pauline introductions in which the phrase occurs. ${ }^{34}$

The famous christological passages in Colossians 1:15ff. and Philippians 2:6ff. were altered. Colossians 1:15-18 was reformulated through omissions to read: ' $\mathrm{He}$ is the image of the invisible God, and he is before all things'. The phrases omitted by Marcion from this passage mostly concern the relationship between Christ and creation: 'the first-born of all creation' (v. 15b), which clearly links Christ to the Creator; the whole of verse 16: 'for in him all things were created. . all things were created through him and for him', which clearly links Christ to the created cosmos; and v. 17b: 'in him all things hold together', which links Christ with the ongoing continuation of the created world.35 Although Marcion's distinctive theology was an important factor in these alterations, we should note the christological implications as well. A clear alteration is made in

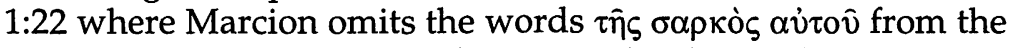
reference to Jesus' body. ${ }^{36}$ The reason for this is obvious, since for Marcion Christ had no flesh.

In Philippians 2:6, 7 Marcion's text read:

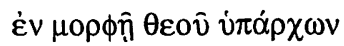

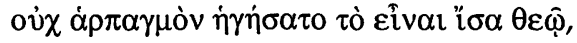

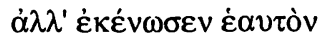

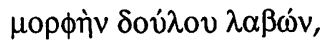

8:11; 1 Cor. 6:14 and Eph. 1:20 Marcion maintains a reference to Christ being raised by the Father (T. Baarda, 'Marcion's Text of Gal 1:1. Concerning the Reconstruction of the First Verse of the Marcionite Corpus Paulinum', VC 42 (1988) 236-256).

322 Cor. 1:3 (Tertullian, Adv. Marc. V.11.1), Rom. 1:7.

${ }^{33}$ It is included. for example. in 1 Cor. 1:3 (Harnack, Marcion, 79*; Tertullian, Adv. Marc. V.5.2).

${ }^{34}$ See Tertullian, Adv. Marc. V.5.1.

${ }^{35} \mathrm{Col}$. 1:18 is not attested in the discussions. Marcion's acceptance of v. 24, and the allusions in Eph. 2:16 \& 5:23 belie the impression that is given by the lack of references to the church as the body of Christ in Harnack's reconstruction (i.e. one cannot find any of the following texts: Rom 12:4, 5; 1 Cor. 10:17; 12:12-24a, 27; Eph. 4:4, 12-16; Col. 1:18; 2:19). Since Tertullian seems to allude to Marcion's acceptance of the concept (in Adv. Marc. V.8.9 \& V.18.8f.) we can conclude that he did accept the idea.

${ }^{36}$ Harnack, Marcion, 122* (Tertullian, Adv. Marc. V.19.6). 
$\dot{\varepsilon} v \dot{\alpha} \mu \mathrm{ol} \omega \dot{\mu} \mu \tau \imath \dot{\alpha} v \theta \rho \omega ́ \pi 0 v^{37}$

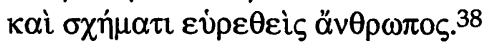

This corresponds to Paul's text except for the omission of $\gamma \varepsilon v o ́ \mu \varepsilon v o \varsigma$ and $\dot{\omega} \varsigma$ from $v$. 7. This passage was central for Marcion and his followers, who took Paul's references to 'the form of a servant' and 'the likeness of men' as teaching the unreality of Christ's flesh. ${ }^{39}$ This interpretation was undoubt-

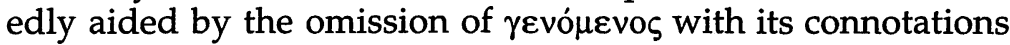
of beginning and birth.

\section{The Euaggelion}

In his gospel the same two factors, theology and Christology, often combine. The Euaggelion opens with the sudden appearance of Jesus in Capernaum, in which Marcion combines material from Luke 3:1a and 4:31:40

37 $\dot{\alpha} v \rho \rho \dot{\pi} \pi 0 v$ with $\mathfrak{P}^{46} ;$ Vgmss; Cyprian.

${ }^{38}$ Harnack, Marcion, $125^{*}$ f. (Tertullian, Adv. Marc. V.20.3).

${ }^{39}$ Tertullian, Adv. Marc. V.20.3-6, cf., also Harnack, Marcion, 126* who notes that this was 'eine Grundstelle der Christologie Marcions'.

${ }^{40}$ Our procedure involves assessing the difference between Marcion's text, as attested by Tertullian and/or Epiphanius, and the NT. This method has been called into question by Williams ('Reconsidering Marcion's Gospel') on the grounds that i) Tertullian and Epiphanius do not quote accurately or consistently from Marcion (p. 478f.; e.g. Tertullian (Adv. Marc. IV.29.1) apparently refers to Luke 12:28, said to be absent by Epiphanius (Schol. 31); and on the other hand Epiphanius (Schol. 71) refers to Luke 23:34, said to be absent by Tertullian (Adv. Marc. IV.24.4)); ii) variations occur between direct and indirect quotations and allusions (p. 479f.); iii) Tertullian criticises Marcion for omitting passages which are not in Luke (p. 480). He concludes that 'for the majority of cases, it is not justifiable to assume that Marcion ever saw what he is accused of omitting' (p. 483).

But Williams exaggerates the problems associated with the evidence of Epiphanius and Tertullian, since variations in patristic quotations occur regularly, for example in gospel citations: this does mean care must be exercised, but it doesn't mean that the testimony of ancient authors can be disregarded (especially when from an apologetic point of view Tertullian et al. had nothing to gain by accusing Marcion of altering Luke rather than using another source). On other issues Williams is, of course, correct to notice firstly that Tertullian did charge Marcion with excising passages found in Matthew (so Mt. 5:17 in Adv. Marc. IV.7.4, 9.15, 12, 14; also Mt. 15:24 \& 26 in Adv. Marc. IV.7.5), and secondly that both Irenaeus (Adv. Haer. III.12.12) and Tertullian (Adv. Marc. IV.5.7) refer to changes made by Marcion's disciples. The resolution of the citation of passages from Matthew (which Williams did not consider) is normally that they come 


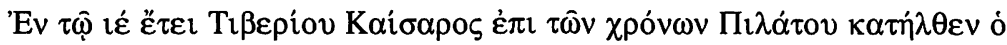

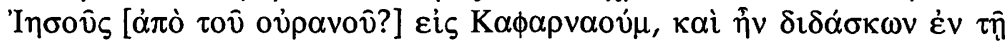

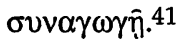

While it is not clear whether or not Marcion's text read àjò $\tau$ ô ovjpavo $v$ in this passage;42 Tertullian certainly took it as signifying a docetic arrival (Adv. Marc. IV.7), and even adds spiritus salutaris after 'come down from heaven' on one occasion when referring to this passage (Adv. Marc. I.19.2). ${ }^{43}$

Marcion's Christology, which denied the fleshly nature of Jesus, precluded any use of the birth narratives (Tertullian, de Carne 2). For him there could be no real birth, no assumption of human nature, because all material things were created by the Creator god. In addition, the Jewishness of the material in Luke's birth narrative, and the human ancestry revealed in the genealogy were not congenial to Marcion. ${ }^{44}$ The connection of Jesus to Nazareth was consistently obscured by Marcion, ${ }^{45}$ and the baptism and temptation were also left out. Luke's insistence on the human development of Jesus was similarly rejected.

from Marcion's Antitheses. This was the position of Harnack (Marcion, 80; he refers to additional passages: Mt. 19:12ff.-cited by Origen, Comm. on Matt. XV.1 on 19:12; Mt. 1:23 etc.-discussed by Tertullian, Adv. Marc. III.12f.; Mt. 19:3-8 discussed by Tertullian, Adv. Marc. IV.34.1f.] and Blackman (Marcion, 48f.; he refers to further passages: Mt. 5:17 revised:

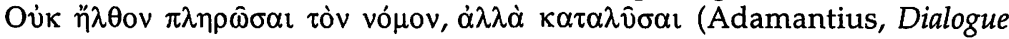
2:15); Mt. 20:20ff. (or Mk. 10:35ff.) alluded to (Origen reports that the Marcionites believed that Paul sat on the right hand of God and Marcion on the left Comm. on Luke 25); Mt. 23:8 (according to Ephraem, Song 24)]. Since Marcion is said to have discussed the relationship between Law and Gospel in the Antitheses (Tertullian, Adv. Marc. I.19) it would be the appropriate place to discuss Mt. 5:17 (one of the most cited and alluded to passages in Tertullian, Adv. Marc. I.23.4; IV.22.11, 42.6 (for allusions); and IV.36.6 (quotation); V.14.14 (extended discussion)).

${ }^{41}$ Tertullian writes (of Marcion's Christ): 'he was brought to birth out of heaven, at once full-grown, at once complete, Christ with no delay, spirit, and power, and god-and nothing more' (Adv. Marc. IV.21.11); cf., III.2.3: 'Suddenly a Son, suddenly Sent, and suddenly Christ!'

${ }^{42}$ Harnack, Marcion, 185*.

43This agrees with Hippolytus' description of Marcion's doctrine: 'independent of birth, (the Logos) Himself descended from above in the fifteenth year of the reign of Tiberius Caesar' (Refutatio VII.19).

${ }^{44} \mathrm{On}$ the genealogy see Irenaeus, Adv. Haer. I.27.2.

45Omitted from Lk. 4:34 (Tertullian, Adv. Marc. IV.8); 18:37 (Harnack, Marcion, 227*). 
Marcion's rejection of the OT combined with his tendency to docetism in order to facilitate the rejection of these chapters. In particular the opening verse could be taken as a major christological signal from Marcion (albeit in guarded form).

The remainder of chapter four was rearranged by Marcion. ${ }^{46}$ The content of Jesus' teaching in the synagogue is omitted. 47 The events following the episode in the synagogue are transferred to after the healing of the demon-possessed man. In this episode the crucial phrase from 4:41: 'because they knew that he was the Christ' was omitted-Jesus could not be the Messiah predicted in the OT. Marcion also omits Luke 5:39: 'the old [wine] is better'; 48 which was presumably thought to support a positive view of the OT (although it appears to be ironical in Luke).

Luke 8:19 (the mother and brothers of Jesus coming to him) is omitted. ${ }^{49}$ Instead, after a report that his mother and brothers are outside, Jesus asks: 'Who is my mother, and who are my brothers?'50 The passage closes with the answer: 'those who hear my words and do them'.51 The whole episode is cast differently from the Lukan (or Synoptic) presentation, and this complex of alterations gives us a view of Marcion's activity. Since Jesus was never born, he could not have a mother and brothers, hence their omission from the narrative. By having Jesus ask 'Who is my mother?' he has Jesus himself testify to

${ }^{46}$ See Harnack, Marcion, $184^{*}-187^{*}$.

47The crucial point for Luke, that the fulfilment of OT promises is announced 'Today', hardly fits with Marcion's framework.

${ }^{48}$ This verse is also omitted in D, it, and by Irenaeus and Eusebius. Metzger ( $A$ Textual Commentary on the Greek New Testament [London, UBS 1975] 138f.) regards this as an example of the influence of Marcion's text on a wider circle of Western witnesses (see I.H. Marshall, The Gospel of Luke (NIGTC; Exeter, Paternoster / Grand Rapids, Eerdmans 1978) 228 for some other alternatives).

${ }^{49}$ On Lk. 8:19-21 see Harnack, Marcion, 198* (Tertullian, Adv. Marc. IV.19; Epiphanius, Schol. 12).

50Tertullian, Adv. Marc. IV.19.6, 10, 11 (with slight differences-Williams, 'Reconsidering Marcion's Gospel', 479 n. 7). This phrase appears to have been 'borrowed' from the Matthean parallel to Luke here at Mt. 12:48 (or Mk. 3:33).

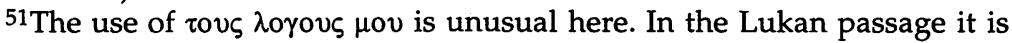
'God's word' (Lk. 8:21), nor does it come from the Matthean parallel; it is perhaps influenced by Mt. 7:24, or Jn. 5:24; the rest of the phrase is from Luke. 
the fact that he had never been born. 52 The final encouragement to those who hear and obey his words, serves to emphasise the place of Jesus in the revelatory plan of the good god, and is perhaps indicative of Marcion's modalism.

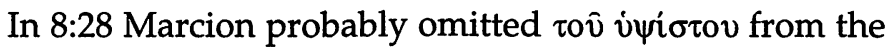
cry of the Gerasene demoniac: 'What have you to do with me Jesus, Son of God the Most High'. ${ }^{53}$ This is presumably not due to any lack of reverence, but because this would involve a relationship between Jesus and the OT God, who is often referred to as God, the Most High. 54

Other examples of Marcion's alterations include the following: in Jesus' prayer in 10:21, not only is $\pi$ óm (weakening the statement of intimacy somewhat), but also kai $\tau \hat{\imath} \varsigma \gamma \hat{\eta} \varsigma$ is omitted (as also by $\mathfrak{P}^{45}$ ). This results in a text where Jesus addresses in prayer 'the God who is Lord of heaven' (in distinction from the 'other god', the Creator god, who was Lord of the earth). In various places $(12: 8,9 ; 15: 10)$ the words $\tau \hat{\omega} v$ $\dot{\alpha} \gamma \gamma \varepsilon \dot{\lambda} \lambda \omega \mathrm{v}$ are omitted, because only the Creator god had angels (cf. 9:26 where the whole verse was omitted). 18:31-33, in which Jesus announces his death and resurrection as being according to the scriptures, is omitted. Zacchaeus is, for Marcion, no longer a son of Abraham, since the whole clause is omitted from the passage (i.e. salvation can come to the household without anyone becoming a son of Abraham!); it appears also that $\zeta \eta \tau \hat{\eta} \sigma \alpha \imath$ was omitted from 19:10. The whole complex of material surrounding the entry into Jerusalem and the cleansing of the temple (19:29-46) is omitted; 20:9-18 (the parable of the vineyard and the tenants) was also omitted. These two omissions stem from the radical discontinuity introduced by Marcion between Jesus and Judaism.

It is a difficult task to reconstruct Marion's passion narrative in any detail. The difficulty of the reconstructive task stems from the lack of information provided by Tertullian and

52Taken this way by Tertullian, Adv. Marc. IV.19.

53Harnack, Marcion, 199*; see discussion in Tertullian, Adv. Marc. IV.20.57.

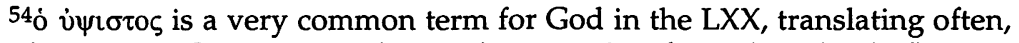

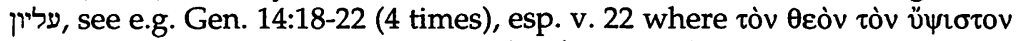

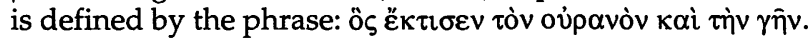


Epiphanius about the narrative of Marcion at this point. 55 Many passages are not referred to in their discussions so one is left with little solid information about possible omissions. ${ }^{56}$ It is certainly likely that the many OT allusions and the quotations in the Lukan passion narrative would have been suppressed. It is well known, of course, that unlike other docetists, he had a firm place for the death of Jesus in his system. ${ }^{57}$ Distinctive of Marcion was the rejection of the birth of Jesus (i.e. involvement with the Creator god), while other docetists rejected his death.

A significant complex of alterations occurred around the account of the Last Supper in Luke 22:14-20. Verses 16-18 were omitted; 58 v. 19b may also have been omitted. Marcion

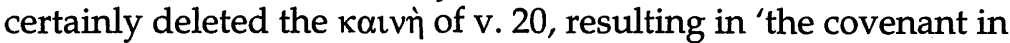
my blood'.59 Various other passages are also omitted from the passion narrative: $22: 23-30 ; 60$ 22:35-38 with the clear statement of the fulfilment of Isaiah's prophecies in Jesus. Jesus' response to the questioning of the Council in 22:70 is divested of its OT allusiveness in that '́ $\gamma \omega$ ' ei $\mu \mathrm{r}$ is omitted. 'King of the Jews' is not included in the Marcion text: 23:36-42 was probably omitted

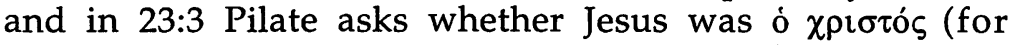
Marcion, Jesus' answer must have been taken negatively). The

55It is worth remembering Tertullian's stated aim to interact with Marcion on the basis of Marcion's text and not to criticise him for his critical principles, see e.g. Adv. Marc. IV.2.

56 One has only to look at Harnack, Marcion, 55-58 and the number of passages which are 'ungewiss', or 'unbezeugt'.

${ }^{57}$ Marcion's doctrine of the atonement revolved around the idea of purchase: Jesus' death was proof of his great love for mankind (Adv. Marc. III.21), and in the cross he purchased/redeemed mankind from the Creator god (Adv. Marc. II.18, 23; V.3,6). Tertullian shows the difficulty in accepting the crucifixion, while not the fleshly suffering of Jesus (de Carne 5); he could not be man if he was not flesh (5; cf., Adv. Marc. III.8 where Tertullian picks up this contradiction in Marcion who explicitly asserts the suffering and death of Christ).

58Verse 16 was certainly omitted, see Harnack, Marcion, 233* (Epiphanius, Schol. 63); there is no direct witness for Marcion's use of verses 17 \& 18.

${ }^{59}$ Harnack, Marcion, 233* (Tertullian, Adv. Marc. IV.40.4). It may be (with Williams, 'Reconsidering Marcion's Gospel', 482f.) that this represents an assimilation to Mt. 26:28, but there is no denying it coheres with Marcion's theological position which could hardly recognise the old covenant (Blackman, Marcion, 46).

${ }^{60}$ Probably omitted, although not actually attested (Harnack, Marcion, $233^{*}$ ), Marcion could hardly have tolerated v. 30 (Harnack, Marcion, 57). 
saying of assurance to the repentant thief "Today you will be with me in paradise' (23:43) is also omitted.

The resurrection account is also not fully attested, although the basic narrative follows the Lukan model. He rejects the important statements of Jesus concerning the fulfilment of the law and the prophets (24:27 and 44-46). In addition 24:39-40 was altered, and reinterpreted, in the interests of his docetic Christology to read: 'A spirit, such as ye see me to be, hath not bones'.61

\section{Conclusion}

There is little doubt that Marcion's redaction of Luke was influenced by christological as well as by his theological convictions. Since his Christology was a product of his doctrine of God (or the gods) this is not surprising, and we shouldn't be tempted to isolate the one from the other. Nevertheless our survey has highlighted the importance of Marcion's Christology in his redactional procedure. The overriding method, as is characteristic of reactionary redaction, was omission; Marcion cuts out material, on both large and small scale, with which he differs. In addition it seems clear that patterns of interpretations were also influential in interpreting the gospel text through Marcion's docetic grid (even when Luke's text was not altered).

61Harnack, Marcion, 239* (Tertullian, Adv. Marc. IV.43.7; Epiphanius, Schol. 78). On this passage as evidencing Marcion's docetism see D. Plooij, 'The Ascension in the "Western" Textual Tradition', Mededeelingen der Koninklijke Akademie van Wetenschappen, Afdeeling Letterkunde (Amsterdam) 67 (1929) 44. 